\title{
Midterm follow-up with exclusive use of arterial grafts in complete myocardial revascularization of patients with triple vessel coronary artery disease
}

\author{
Seguimento clínico a médio prazo com uso exclusivo de enxertos arteriais na revascularização completa \\ do miocárdio em pacientes com doença coronária triarterial
}

Luiz Augusto F. LISBOA, Luís Alberto O. DALLAN, Luiz Boro PUIG, Carlos ABREU FILHO, Ricardo Cerquinho LECA, Luís Augusto P. DALLAN, Sérgio Almeida de OLIVEIRA

RBCCV 44205-663

\begin{abstract}
Objective: To evaluate the midterm benefits of exclusive use of arterial grafts in patients with triple vessel coronary arteriosclerotic disease who underwent complete coronary artery bypass grafting.

Method: Between July 1995 and July 1997, 137 consecutive patients with triple vessel coronary atherosclerotic disease underwent complete coronary artery bypass grafting exclusively using arterial grafts. Of these patients, $112(81.7 \%)$ were male, with ages ranging from 36 to 78 years old (mean 56.5 years). Three hundred and sixty-three arterial grafts were used to perform 442 coronary anastomoses, an average of 3.2 coronary anastomoses per patient. The arterial grafts used were left internal thoracic artery $(99.3 \%)$, right internal thoracic artery $(56.2 \%)$, radial artery $(94.9 \%)$, right gastroepiploic artery (13.9\%) and inferior epigastric artery $(0.7 \%)$. In 80 (58.4\%) patients, arterial composite "Y" grafts were constructed with the left internal thoracic artery and another arterial graft.

Results: No operative deaths occurred. Four (2.9\%) deaths occurred in the postoperative period and only one $(0.7 \%)$
\end{abstract}

patient needed reoperation in the immediate follow-up. The 7-year actuarial survival was $94.0 \%$ and the event free probability (myocardial infarction, angioplasty, reoperation or death) was $87.0 \%$.

Conclusions: Good early and midterm clinical follow-ups can be achieved by exclusively using arterial grafts in the complete coronary artery bypass grafting of patients with triple vessel coronary arteriosclerotic disease. A long-term follow-up will be necessary to show the influence of exclusive use of arterial grafts in the surgical treatment of coronary insufficiency.

Descriptors: Miyocardial revascularization. Mammary arteries. Arteriosclerosis.

\section{Resumo}

Objetivo: Avaliar os benefícios a médio prazo do uso exclusivo de enxertos arteriais em pacientes com doença aterosclerótica coronária triarterial submetidos à revascularização completa do miocárdio.

Heart Institute of the Hospital das Clínicas, Medical School, University of São Paulo (InCor HC - FMUSP)

Correspondence address: Luiz Augusto Ferreira Lisboa. Rua João Alvares Soares, 1456 Ap. 102. São Paulo, SP. CEP: 04609-003. Tel: (11) 3069-5014.

E-mail: dcilisboa@incor.usp.br 
Método: Entre julho/95 e julho/97, 137 pacientes consecutivos foram submetidos à revascularização miocárdica com uso exclusivo de enxertos arteriais. Destes, 112 (81,7\%) eram do sexo masculino e a idade variou de 36 a 78 anos (média de 56,5 anos). Foram utilizados 363 enxertos arteriais, sendo realizadas 442 anastomoses coronárias; média de 3,2 anastomoses coronárias por paciente. Os enxertos arteriais utilizados foram a artéria torácica interna esquerda $(99,3 \%)$, artéria torácica interna direita $(56,2 \%)$, artéria radial $(94,9 \%)$, a artéria gastroepiplóica direita $(13,9 \%)$ e a artéria epigástrica inferior $(0,7 \%)$. Em $80(58,4 \%)$ pacientes foram construídos enxertos arteriais compostos, com anastomose em "Y" da artéria torácica interna esquerda com outro enxerto arterial.

Resultados: Não houve mortalidade operatória. Ocorreram quatro $(2,9 \%)$ óbitos durante o período de internação

\section{INTRODUCTION}

The internal thoracic artery (ITA) has been recognized as the best graft for coronary artery bypass grafting $(\mathrm{CABG})$ [1]. Its advantages increase with the passing of time, suggesting that the initial choice of this graft is a more important survival factor than the progression of arteriosclerotic disease in the coronary artery [2]. However, the main cause of recurrent angina and of reoperation is the progression of the arteriosclerosis in the saphenous vein (SV) graft $[3,4]$. The number of patients who require reoperations owing to the progression of the arteriosclerosis in the SV grafts and who present with the left internal thoracic artery (LITA) patent anastomised on the anterior descending coronary artery $(\mathrm{AD})$ is increasing.

The long-term advantages of the use of both the ITAs in CABG were recently demonstrated [5]. However, in the majority of patients with indications of surgical treatment of coronary insufficiency presenting with triple artery disease, the use of both the ITAs is frequently insufficient for total CABG. Several authors have suggested the use of other arterial grafts such as the radial artery (RA) [6], the right gastroepiploic artery (RGEA) [7] and the lower epigastric artery (LEA) [8] to complete total $C A B G$ with multiple arterial grafts.

In this work we studied the initial and mid-term advantages of the exclusive use of arterial grafts in patients with coronary arteriosclerotic disease involving three arteries submitted to total CABG.

\section{METHOD}

Between July 1995 and July 1997, 137 consecutive patients submitted to total CABG exclusively utilized arterial grafts. All the patients presented with triple coronary artery hospitalar e apenas um $(0,7 \%)$ paciente necessitou ser reoperado no seguimento inicial. A probabilidade livre de eventos cardíacos (infarto do miocárdio, angioplastia, reoperação ou óbito) foi de $87,0 \%$ e a sobrevida foi de $94,0 \%$ com sete anos de seguimento clínico.

Conclusões: $O$ uso exclusivo de enxertos arteriais na revascularização completa do miocárdio em pacientes com doença aterosclerótica coronária triarterial apresenta bons resultados imediatos e a médio prazo. $O$ acompanhamento desses pacientes a longo prazo nos mostrará a influência do uso exclusivo de enxertos arteriais no tratamento cirúrgico da insuficiência coronária.

Descritores: Revascularização miocárdica. Artérias mamárias. Arteriosclerose.

arteriosclerotic disease and were submitted to surgical treatment in the Heart Insttute of the Hospital das Clínicas of the Medical School of the University of São Paulo.

One hundred and twelve $(81.7 \%)$ patients were male and the ages ranged from 36 to 78 years (mean of 56.5 years). Twenty-seven (19.7\%) patients were diabetics, 40 (29.2\%) had histories of myocardial infarction and $10(7.3 \%)$ had been previously submitted to CABG (Table 1). Coronary insufficiency was manifested as acute myocardial infarction in $28(20.4 \%)$ patients, unstable angina in $38(27.7 \%)$, stable angina in $60(43.8 \%)$ and $11(8.0 \%)$ patients were asymptomatic (Figure 1).

Table 1. Pre-operative characteristics of the patients $(\mathrm{N}=137)$

\begin{tabular}{ll}
\hline Characteristics & $\mathbf{N}^{\mathbf{0}}$ of patients (\%) \\
\hline Age $>70$ years & $18(13.1)$ \\
Gender - male & $112(81.7)$ \\
Systemic arterial hypertension & $77(56.2)$ \\
Smokers & $69(50.3)$ \\
Dyslipidemia & $52(38.0)$ \\
Family history & $41(29.9)$ \\
Prior myocardial infarction & $40(29.2)$ \\
Diabetes mellitus & $27(19.7)$ \\
Bilateral saphenectomy & $11(8.0)$ \\
CRI & $8(5.8)$ \\
COPD & $5(3.6)$ \\
Prior angioplasty & $5(3.6)$ \\
Reoperation & $10(7.3)$ \\
\hline
\end{tabular}

COPD $=$ Chronic obstructive pulmonary disease, $\mathrm{IRC}=$ Nondiabetic chronic renal insufficiency 
Pre-operative cineangiography demonstrated the involvement of the left coronary artery branch in $25(18.2 \%)$ patients, normal function of the left ventricle in $83(60.6 \%)$ patients, moderate dysfunction in $35(25.5 \%)$ and significant dysfunction (ejection fraction $=35 \%$ ) in $19(13.9 \%)$ - Table 2 .

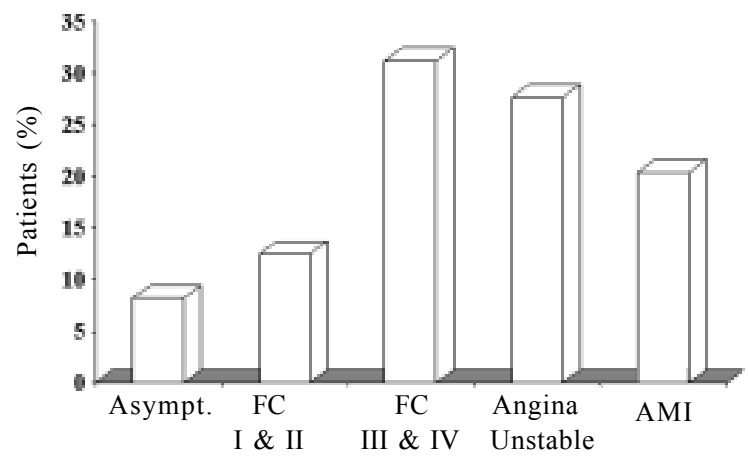

Asympt. $=$ Asymptomatic; $\mathrm{FC}=$ Angina functional class, $\mathrm{AMI}=$ Acute myocardial infarction

Fig. 1 - Distribution of patients according to clinical symptoms

Table 2: Pre-operative coronary cineangiography of the patients $(\mathrm{N}=137)$

\begin{tabular}{ll}
\hline Characteristics & $\mathbf{N}^{\mathbf{0}}$ of patients (\%) \\
\hline $\begin{array}{l}\text { Triple coronary } \\
\text { artery involvement }\end{array}$ & $137(100)$ \\
LCB involvement & $25 \quad(18.2)$ \\
EF $=55 \%$ & $83(60.6)$ \\
EF between $35 \%$ and $55 \%$ & $35(25.5)$ \\
EF $=35 \%$ & $19(13.9)$ \\
\hline
\end{tabular}

$\mathrm{EF}=$ Left ventricle ejection fraction, $\mathrm{LCB}=$ Left coronary artery branch

\section{Surgical technique}

The approach employed was median sternotomy and CABG was performed with the help of cardiopulmonary bypass. Installation of cardiopulmonary bypass was achieved by the classic technique utilizing, after systemic heparinization of the patient ( $500 \mathrm{IU} / \mathrm{kg}$ ), a No 22 or 24 cannula in the ascending aorta and a single two-part venous cannula to drain the inferior vena cava and right atrium. $\mathrm{A} \mathrm{N}^{\circ} 14$ catheter was positioned at the aortic root and connected to a aspirator of the heart-lung machine for continuous suction of blood, preventing hypertension, distension and consequent subendocardial ischemia of the left ventricle. Myocardial protection was achieved by intermittent clamping of the aorta or with an anterograde sanguineous cardioplegia solution.

After establishing the cardiopulmonary bypass and inducing cardiac arrest, the $\mathrm{CABG}$ itself was initiated. All the coronary arteries responsible for the perfusion of the great myocardial areas and which presented with significant obstructive lesions $(=70 \%)$ were treated. The end-to-side distal anastomosis of the graft with the coronary artery was preformed first. The proximal anastomosis of the graft with the aorta was made with the patient still under cardiopulmonary bypass and with total aortic clamping. The Y-shaped anastomosis of the compound grafts was preformed at the end of the cardiopulmonary bypass, with the heart beating.

\section{Surgical Procedure}

A total of 363 arterial grafts were used, making a total of 442 coronary anastomoses, an average of 3.2 per patient. The LITA was utilized in 136 (99.3\%) patients and the right internal thoracic artery (RITA) in 77 (56.2\%). Both ITAs were utilized in 76 (55.5\%) patients, with the RITA freely used as a Y-shaped compound graft with the LITA in $32(42.1 \%)$ of the cases. The RA was utilized in $130(94.9 \%)$ patients, where in $48(36.9 \%)$ cases it was anastomosed in a Y-shape to the LITA. The RGEA was utilized in 19 (13.9\%) patients and the LEA in $1(0.7 \%)$ patient.

CABG of the branches of the left coronary artery were normally performed with both ITAs. The LITA, in situ and retro-aortic, was used in grafting to the left marginal arteries. In the cases where the RITA, "in situ", was not long enough to reach the circumflex coronary artery branches, this was used as a free graft, anastomosed in a Y-shape on the LITA (Figure 2).

The RA was preferred in situations of sequential anastomosis in which more than one branch of the left coronary artery (diagonal, left marginal or posterior ventricular (PV) arteries) required revascularization (Figure 3). The free graft was anastomised to the aorta or as a compound Y-shape graft with the LITA. In patients with pneumopathies, obesity or diabetes, the RA was also preferred in relation to the RITA.

The RGEA, "in situ", was utilized in critical lesions or occlusion of the right coronary artery (RC) to revascularize the posterior descending (PD) branches or the PV (Figure 4). 


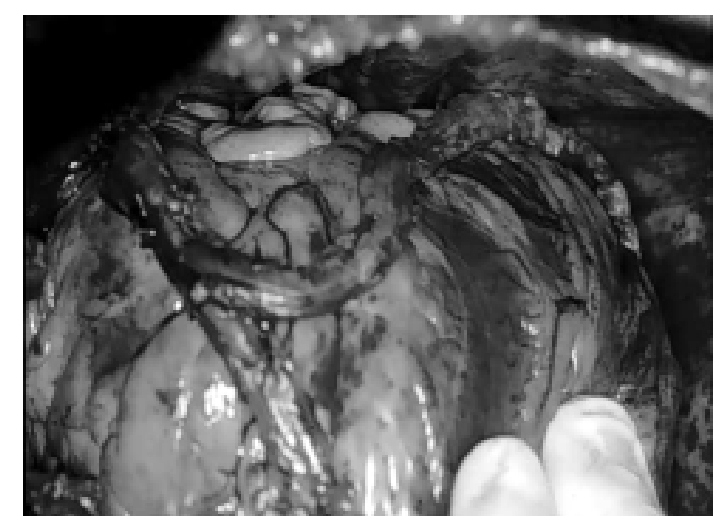

Fig. 2 - Intra-operative view. Y-shape anastomosis of the right internal thoracic artery (RITA) to the left internal thoracic artery (LITA) for the revascularization of the left coronary artery branches

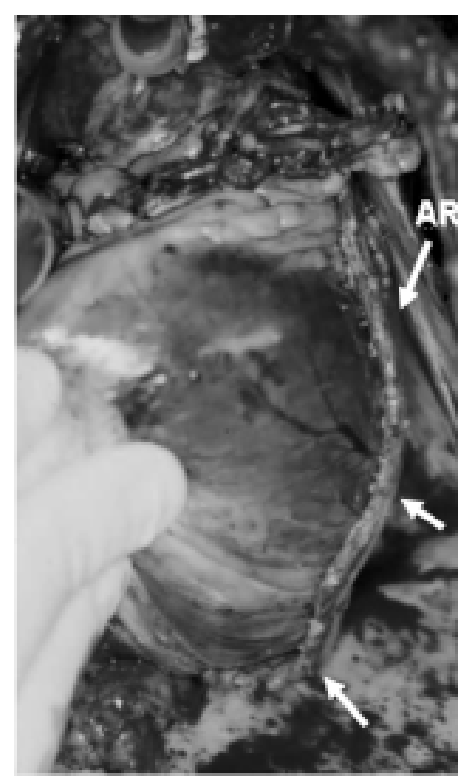

Fig. 3 - Intra-operative view. Sequential anastomoses of the radial artery (RA) with two marginal coronary arteries and the posterior ventricular branch of the circumflex artery

The arterial grafts utilized, as well as the respective anastomoses with the coronary arteries are described in Table 3.

\section{RESULTS}

There were no operative mortalities. Myocardial protection was performed using intermittent clamping of the ascending aorta in $83(60.5 \%)$ patients and in $54(39.5 \%)$ patients a sanguineous cardioplegia solution was used. The CPB time ranged from 51 to 228 minutes (mean 103.5 minutes). Three $(2.1 \%)$ patients presented with significant hemodynamic instability after removal of the CPB and required the use of an intra-aortic balloon. Transfusions of concentrated red blood cells during the operation were necessary in $69(50.3 \%)$ patients.

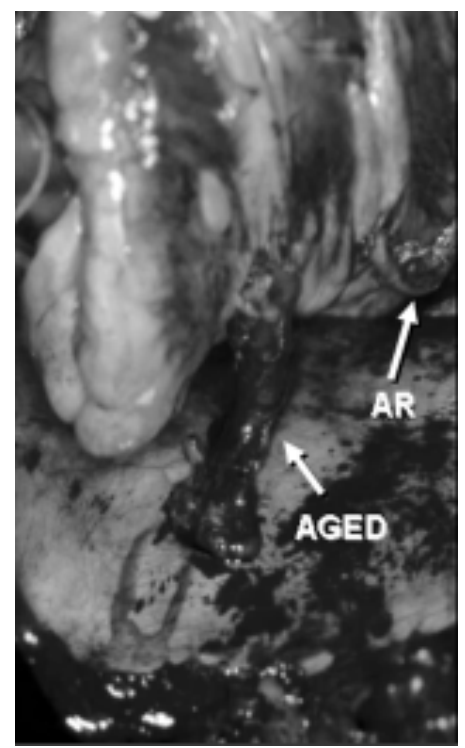

Fig. 4 - Right gastroepiploic artery (RGEA) "in situ” anastomosed to the posterior descending coronary artery and the radial artery (RA) anastomosed to the posterior ventricular coronary artery

Table 3: Arterial grafts utilized and respective anastomoses to the coronary arteries

\begin{tabular}{lcccccc}
\hline & LITA & RITA & RA & RGEA & AEI & TOTAL \\
\hline $\mathrm{AD}$ & 135 & 1 & - & - & - & 136 \\
$\mathrm{DI} / \mathrm{LM}$ & 12 & 60 & 155 & 1 & 1 & 229 \\
$\mathrm{RC}$ & - & 2 & - & - & - & 2 \\
$\mathrm{PD} / \mathrm{PV}$ & - & 19 & 38 & 18 & - & 75 \\
TOTAL & 147 & 82 & 193 & 19 & 1 & 442 \\
\hline
\end{tabular}

LITA $=$ Left internal thoracic artery, RITA = right internal thoracic artery, RA = Radial artery, RGEA = right gastroepiploic artery, $\mathrm{IEA}=$ inferior epigastric artery, $\mathrm{RC}=$ right coronary artery, $\mathrm{AD}=$ anterior descending, $\mathrm{DI}=$ diagonal, $\mathrm{PD}=$ posterior descending, $\mathrm{PV}=$ posterior ventricular, $\mathrm{LM}=$ left marginal

Three (2.2\%) patients required reoperations to review of the hemostasis. Five (3.6\%) patients presented with elevated enzyme levels suggestive of acute myocardial infarction (AMI), however only in three $(2.2 \%)$ patients this was 
with triple vessel coronary artery disease

associated to electrocardiographic alterations characterizing AMI. One $(0.7 \%)$ patient who coursed with AMI of the anterior wall of the left ventricle required reoperation. In the surgery, the anastomosis of the LITA with the AD developed thrombi and was re-made. Three (2.2\%) patients presented with strokes in the postoperative period, although only one $(0.7 \%)$ evolved with sequelae. Mediastinitis was diagnosed in three $(2.2 \%)$ patients, however all had a good clinical evolution. The main complaints presented in the postoperative period are listed in Table 4.

Four $(2.9 \%)$ deaths occurred during hospitalization. One of the patients who passed away had undergone the second CABG reoperation and another presented with an acute phase of AMI. The causes of the hospital morbidities are listed in Table 5.

Table 4: Complications in the immediate postoperative period $\left(\mathrm{N}^{\circ}=29 / 137-21.0 \%\right)$

\begin{tabular}{ll}
\hline Complication & $\mathbf{N}^{\mathbf{0}}$ of patients $(\%)$ \\
\hline Pulmonary infection & $13(9.5)$ \\
Atrial fibrillation & $12(8.8)$ \\
Renal insufficiency & $4(2.9)$ \\
Acute myocardial infarction & $3(2.2)$ \\
Stroke & $3(2.2)$ \\
Mediastinitis & $3(2.2)$ \\
Bleeding & $3(2.2)$ \\
\hline
\end{tabular}

Table 5. Causes of hospital mortality $\left(\mathrm{N}^{\mathrm{o}}=4 / 137-2.9 \%\right)$

\section{Cause} $\mathrm{N}^{0}$ of patients $(\%)$

Upper digestive tract hemorrhage/Sepsis $1(0.7)$

Acute myocardial infarction/cardiogenic shock $1(0.7)$

Peripheral arterial insufficiency/Sepsis $\quad 1(0.7)$

Ischemic stroke/Sepsis

The late clinical follow up of the patients varied from 5 to 7 years, with a mean of $5.7 \pm 1.6$ years. In this period four (2.9\%) deaths occurred and $6(4.5 \%)$ patients presented with relapse of the angina; five clinically controlled and one reoperated. The cardiac event-free probability (myocardial infarction, angioplasty, re-operation or death) was $87.0 \% \pm$ $4.0 \%$ and the survival rate was $94.0 \% \pm 2.0 \%$ with up to 7 years of follow up (Figures 5 and 6).

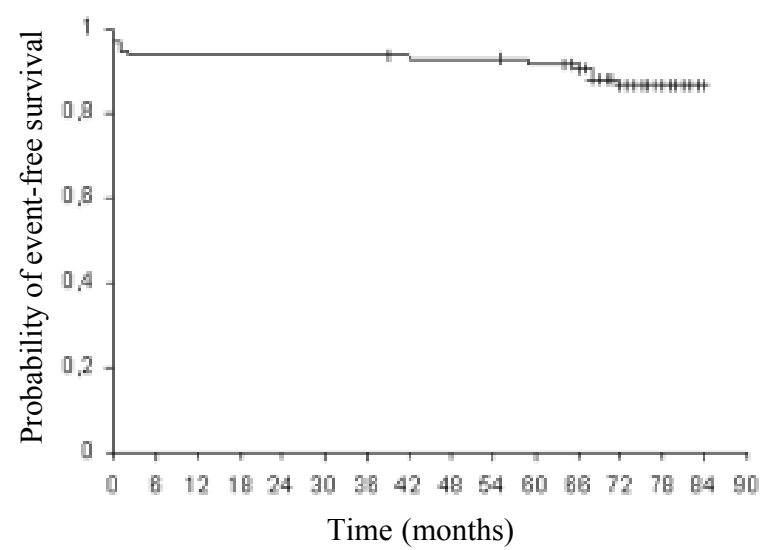

\begin{tabular}{cccc}
\hline $\begin{array}{c}\text { Time } \\
\text { (months) }\end{array}$ & $\begin{array}{c}\text { probability of } \\
\text { survival }\end{array}$ & $\begin{array}{c}\text { Standard } \\
\text { error }\end{array}$ & $\begin{array}{c}\mathrm{N}^{\circ} \text { at } \\
\text { risk }\end{array}$ \\
\hline 0 & 1.00 & 0.00 & 97 \\
6 & 0.94 & 0.02 & 91 \\
12 & 0.94 & 0.02 & 91 \\
24 & 0.94 & 0.02 & 91 \\
36 & 0.94 & 0.02 & 91 \\
48 & 0.93 & 0.03 & 89 \\
60 & 0.92 & 0.03 & 87 \\
72 & 0.87 & 0.04 & 58 \\
84 & 0.87 & 0.04 & 0 \\
\hline
\end{tabular}

Fig. 5 - Probability of survival free of cardiac events (acute myocardial infarction, angioplasty, reoperation and death) with up to 7 years of clinical follow up (Kaplan-Meier method). The table illustrates the number of at-risk patients in the different follow-up periods

\section{COMMENTS}

The evolution of coronary arteriosclerotic disease has been positively influenced by the improvements in its surgical treatment. The immediate and long-term benefits of CABG are well known particularly when the LITA is used for the graft $[9,10]$. The importance of anastomosis of the LITA and the AD has been understood since the end of the 1970s, but only recently the long-term advantages with the use of both the ITAs in CABG have been demonstrated [5]. 


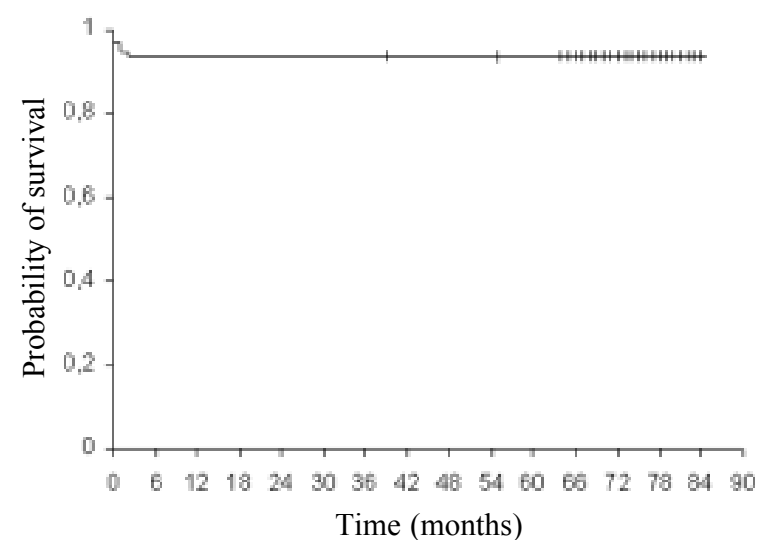

\begin{tabular}{cccc}
\hline $\begin{array}{c}\text { Time } \\
\text { (months) }\end{array}$ & $\begin{array}{c}\text { probability of } \\
\text { survival }\end{array}$ & $\begin{array}{c}\text { Standard } \\
\text { error }\end{array}$ & $\begin{array}{c}\mathrm{N}^{\mathrm{o}} \text { at } \\
\text { risk }\end{array}$ \\
\hline 0 & 1.00 & 0.00 & 97 \\
6 & 0.94 & 0.02 & 91 \\
12 & 0.94 & 0.02 & 91 \\
24 & 0.94 & 0.02 & 91 \\
36 & 0.94 & 0.02 & 91 \\
48 & 0.94 & 0.02 & 90 \\
60 & 0.94 & 0.02 & 89 \\
72 & 0.94 & 0.02 & 62 \\
84 & 0.94 & 0.02 & 0 \\
\hline
\end{tabular}

Fig. 6 - Probability of survival with up to 7 years of clinical follow up (Kaplan-Meier method). The table illustrates the number of atrisk patients in the different follow-up periods

On the other hand, the choice of grafts for CABG has become complicated as, with the development of interventionalist cardiology, the majority of the patients with single or double arterial coronary disease have been submitted to percutaneous revascularization, with surgical CABG mainly reserved for patients with multiple artery coronary disease.

Currently, the majority of the patients with multiple artery coronary disease are submitted to CABG using the LITA, or less frequently both ITAs, in combination with SV grafts. However, the SV, utilized as a graft, suffers from endothelial proliferation when connected to the arterial circulation and, after some years, it can develop obstructive disease. The main cause of obstructive disease is thrombosis, between the 5 th and 10 th postoperative year, with the consequence of relapse of the angina and the necessity of re-operation $[3,4]$.

Aiming at expanding the use of both ITAs, some authors started to use compound grafts, such as the RITA anastomosed in a Y- or T-shape with the LITA, to revascularize all the branches of the left coronary artery with arterial grafts $[13,14]$. Nevertheless, with this technique the right coronary artery is not approached and revascularization of its branches becomes difficult. The use of the RA or RGEA to compliment revascularization, specifically of the right coronary artery and its branches becomes more attractive $[15,16]$. In our series, compound grafts with Y-shape anastomosis were utilized in $80(58.4 \%)$ patients.

The number of patients operated on using this technique has increased in the majority of heart surgery centers and surgeons are becoming more familiar with the procedure. They have increased their knowledge of the different arterial grafts and, despite the rapid evolution in the use of these grafts that has taken place over the last years, the influence of the use of multiple arterial grafts in CABG has been controversial.

Total revascularization with the use of only arterial grafts presents some limitations, such as: prolonged operative time, increased bleeding, graft spasms with perioperative myocardial hypoperfusion and a greater risk of infection.

The increase in the operative time is more related to the preparation of the arterial grafts, as only the RA can be dissected concomitant to the sternotomy. The dissection of the RITA and principally the RGEA, increase the operative time. However, the CPB time was not influenced by the greater number of anastomoses with arterial grafts. In our study, the average time of CPB of 103 minutes was not significantly greater than the mean time used to perform this type of operation using venous grafts. The bleeding was also not important as approximately $50 \%$ of the patients did not require intraoperative transfusions.

Infectious problems are more related to the use of both ITAs, owing to the greater incidence of mediastinitis when utilizing this technique. This complication is more common in insulin-dependent diabetic patients and thus this technique is contraindicated in respect to this group. In our series, three $(2.2 \%)$ patients presented with mediastinitis in the postoperative period. In two, both ITAs had been used, one of whom was also diabetic. All had a good clinical evolution. In obese patients, with pneumopathies or diabetes we tried to avoid the use of both ITAs and preferred to use the RA instead.

Spasms of arterial grafts can be prevented by the topical administration of heated papaverine solution, careful dissection of the grafts, maintenance of an adequate perfusion pressure both during and after CPB, and the administration of vasodilators such as nitroglycerine and sodium nitroprusside in the intraoperative and immediate postoperative periods. Calcium channel blockers, when necessary, can also be 
useful. Among our patients, 3 (2.2\%) presented with low postoperative cardiac outputs and required intra-aortic balloons, which may have been related to spasms of the arterial grafts.

Postoperative myocardial hypoperfusion might be caused by a series of factors, such as: problems with the arterial grafts (inadequate length, spasms or curving) or technical problems of the anastomoses. Among our 137 patients, one $(0.7 \%)$ presented with postoperative acute myocardial infarction with significant hemodynamic repercussions and requiring reoperation. In the reoperation, the presence of thrombi in the anastomosis of the LITA graft to the anterior interventricular branch was evidenced and the anastomosis was remade and the patient evolved satisfactorily.

The occurrence of myocardial infarction during $\mathrm{CABG}$ surgeries with the exclusive use of arterial grafts is a subject frequently reported in the literature. Some authors affirm that the incidence of complications is low and the use of arterial grafts, especially of the LITA anastomosed on the $\mathrm{AD}$, reduces the incidence of low cardiac output syndrome, peri-operative infarction and operative mortality and improves survival $[18,19]$. In our cohort, we observed $3(2.2 \%)$ cases of peri-operative infarction related to patients operated on in the acute phase of AMI or with unstable angina. The presence of a lesion in the branch of the left coronary artery did not influence the occurrence of postoperative infarction. The mortality of $2.9 \%$ (4 patients) was also more related to the prior clinical conditions of the patients than with the use of arterial grafts. In one patient it was the second reoperation, a second was operated on in the acute phase of AMI which evolved with complications owing to the use of the interaortic balloon and another an aged patient with calcification of the aorta evolved with postoperative stroke and death.

The probability of cardiac event-free (myocardial infarction, reoperation, angioplasty or death) in a 7-year follow-up period was $8.7 \%$. Only one patient required reoperation in this period for occlusion of the RA sequentially anastomosed to two left marginal arteries. The overall survival rate was $94.0 \%$ in the same period. Other studies, with mid-term follow ups, also demonstrated good results with $\mathrm{CABG}$ with the exclusive use of arterial grafts [20].

This work aimed at evaluating the immediate and midterm clinical results of CABG with the exclusive use of arterial grafts, showing good results in terms of survival and event-free rates. However, there is a limitation by not using cineangiographic studies to demonstrate the patency of the grafts. Protocols with late cineangiographic studies and comparisons with a group of patients submitted to CABG surgery with the LITA associated with SV grafts are necessary for a better assessment of the influence of the exclusive use of arterial grafts in total CABG

\section{CONCLUSION}

In conclusion, the exclusive use of arterial grafts in total $\mathrm{CABG}$ in patients with multiple coronary artery atherosclerotic disease gives good immediate and midterm results. The adequate selection of the patients to be submitted to this technique may improve even further the results.

\section{BIBLIOGRAPHIC REFERENCES}

1. Loop FD. Internal-thoracic-artery grafts. Biologically better coronary arteries. N Engl J Med 1996; 334:263-5.

2. Cameron A, Davis KB, Green G, Schaff HV. Coronary bypass surgery with internal thoracic- artery grafts: effects on survival over a 15-year period. N Engl J Med 1996; 334:216-9.

3. Lytle BW, Loop FD, Cosgrove DM, Taylor PC, Goormastic $\mathrm{M}$, Peper $\mathrm{W}$ et al. Fifteen hundred coronary reoperations: results and determinants of early and late survival J Thorac Cardiovasc Surg 1987; 93:847-59.

4. Fitzgibbon GM, Kafka HP, Leach AJ, Keon WJ, Hooper GD, Burton JR. Coronary bypass graft fate and patient outcome: angiographic follow-up of 5,065 grafts related to survival and reoperation in 1,388 patients during 25 years. J Am Coll Cardiol $1996 ; 28: 616-26$.

5. Lytle BW, Blackstone EH, Loop FD, Houghtaling PL, Arnold $\mathrm{JH}$, Akhrass R et al. Two internal thoracic artery grafts are better than one. J Thorac Cardiovasc Surg 1999; 117:855-72.

6. Acar C, Jebara VA, Portoghese M, Beyssen B, Pagny JY, Grare $\mathrm{P}$ et al. Revival of the radial artery for coronary artery bypass grafting. Ann Thorac Surg 1992; 54:652-60.

7. Suma H, Fukumoto H, Takeuchi A. Coronary artery bypass grafting by utilizing in situ right gastroepiploic artery: basic study and clinical application. Ann Thorac Surg 1987;44:394-7.

8. Puig LB, Ciongolli W, Cividanes GV, DontosA, Kopel L, Bittencourt $\mathrm{D}$ et al. Inferior epigastric artery as a free graft for myocardial revascularization. J Thorac Cardiovasc Surg 1990; 99:251-5. 

with triple vessel coronary artery disease

9. Barner HB, Standeven JW, Reese J. Twelve-year experience with internal mammary artery for coronary artery bypass. J Thorac Cardiovasc Surg 1985; 90:668-75.

10. Loop FD, Lytle BW, Cosgrove DM, Stewart RW, Goormastic $\mathrm{M}$, Williams GW et al. Influence of the internal-mammaryartery graft on 10 -year survival and other cardiac events. N Engl J Med 1986; 314:1-6.

11. Bulkley BH, Hutchins GM. Accelerated "atherosclerosis": a morphologic study of 97 saphenous vein coronary artery bypass grafts. Circulation 1977; 55:163-9.

12. Campeau L, Enjalbert M, Lespérance J, Vaislic C, Grondin $\mathrm{CM}$, Bourassa MG. Atherosclerosis and late closure of aortocoronary saphenous vein grafts: sequential angiographic at 2 weeks, 1 year, 5 to 7 years, and 10 to 12 years after surgery. Circulation 1983; 68(3 pt 2):II 1-7.

13. Chocron S, Etievent JP, Schiele F, Clement F, Alwan K, Cordier A et al. The $\mathrm{Y}$ graft: myocardial revascularization with both internal thoracic arteries: evaluation of eighty cases with coronary angiographic assessment. J Thorac Cardiovasc Surg 1994; 108:736-40.

14. Tector AJ, Amundsen S, Schmahl TM, Kress DC, Peter M. Total revascularization with T grafts. Ann Thorac Surg 1994; 57:33-9.
15. Calafiore AM, Di Giammarco G, Luciani N, Maddestra N, Di Nardo E, Angelini R. Composite arterial conduits for a wider arterial myocardial revascularization. Ann Thorac Surg 1994; 58:185-90.

16. Jegaden O, Eker A, Montagna P, Ossette J, De Gevigney G, Finet $\mathrm{G}$ et al. Risk and results of bypass grafting using bilateral internal mammary and right gastroepiploic arteries. Ann Thorac Surg 1995; 59:955-60.

17. Pick AW, Orszulak TA, Anderson BJ, Schaff HV. Single versus bilateral internal mammary artery grafts: 10 - year outcome analysis. Ann Thorac Surg 1997; 64:599-605.

18. Borger MA, Cohen G, Buth KJ, Rao V, Bozinovski J, LiaghatiNasseri $\mathrm{N}$ et al. Multiple arterial grafts: radial versus right internal thoracic arteries. Circulation 1998; 98 (19 Suppl): II 7-14.

19. Tatoulis J, Buxton BF, Fuller JA, Royse AG. Total arterial coronary revascularization: techniques and results in 3,220 patients. Ann Thorac Surg 1999; 68:2093-9.

20. Grandjean JG, Voors AA, Boonstra PW, Heyer P, Ebels T. Exclusive use of arterial grafts in coronary artery bypass operations for three-vessel disease: use of both thoracic arteries and the gastroepiploic artery in 256 consecutive patients. J Thorac Cardiovasc Surg 1996; 112:935-42. 